\title{
THE RELATIONSHIP BETWEEN SOCIO DEMOGRAPHIC CHARACTERISTICS, HEALTH BEHAVIORS, AND BIOCHEMICAL PARAMETERS AND NUTRITIONAL STATUS IN PATIENTS WITH CORONARY HEART DISEASE - A CROSS-SECTIONAL STUDY
}

\section{VEZA IZMEĐU SOCIODEMOGRAFSKIH KARAKTERISTIKA, ZDRAVSTVENIH NAVIKA, BIOHEMIJSKIH PARAMETARA I UHRANJENOSTI KOD BOLESNIKA SA KORONARNOM BOLEŚĆU-STUDIJA PRESEKA}

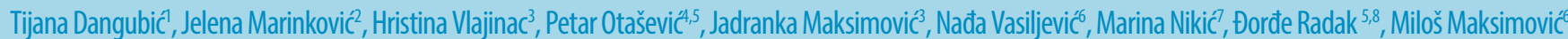

\section{Summary}

According to the World Health Organization (WHO), cardiovascular diseases are the major cause of death in the world.

The aim of the study was to investigate whether nutritional status, assessed by body mass index (BMI), is related to clinical manifestations of coronary heart disease (CHD) as well as to socio-demographic characteristics, health behaviors, and biochemical parameters of CHD patients.

This cross-sectional study included consecutive patients with acute coronary syndrome and stable angina pectoris treated at the General Hospital in Pancevo from December 2012 to May 2013. Patients'demographic, anthropometric and clinical data were collected.

The study group comprised 300 patients with CHD, 174 (56.8.00\%) men and 126 (42.00\%) women. Out of them 68 patients (22.7\%) had normal weight, 133 (44.3\%) were overweight and 99 (33.0\%) were obese. Patients with stable angina pectoris and those with acute coronary syndrome did not significantly differ in their BMI. According to the multivariate logistic regression analyses in comparison with normal weight, overweight and obesity were significantly related to increased level of triglycerides, and obesity was also significantly related to diabetes mellitus type 2 and negatively to retirement.

The results obtained indicate association of increased BMI with other CHD risk factors and thus suggest the need of health education concerning lifestyle habits in order to prevent overweight and obesity.

Keywords: nutritional status, coronary heart disease, health habits

\section{Sažetak}

Prema podacima Svetske zdravstvene organizacije (SZO) kardiovaskularne bolesti su glavni uzročnik umiranja u svetu.

Cilj ovog istraživanja bio je da se ispita da li nutritivni status, procenjen putem Indeksa telesne mase (ITM) utiče na kliničku manifestaciju koronarne bolesti srca, kao i da se procene socio-demografske karakteristike, zdravstveno ponašanje i biohemijski parametri ispitivanih pacijenata.

Rađena je studija preseka kojom su obuhvaćeni pacijenti oboleli od akutnog koronarnog sindroma i stabilne angine pectoris lečenih u Opstoj bolnici Pančevo u periodu od decembra 2012. godine do maja meseca 2013. godine. Sakupljeni su demografski, antropometrijski i klinički podaci pacijenata.

Ispitivanu grupu činilo je 300 pacijenata sa koronarnom bolešću srca, od toga je bilo 174 (56,8\%) muškaraca i 126 (42,00\%) žena. Od ukupnog broja pacijenata njih 68 (22,7\%) imalo je normalnu telesnu težinu, $133(44,3 \%)$ bilo je predgojazno a 99 pacijenata (33,0\%) bilo je gojazno. Pacijenti sa stabilnom anginom pectoris i oni sa akutnim koronarnim sindromom nisu se značajno razlikovali po vrednostima ITM. Prema multivarijantnoj logistickoj regresijonoj analizi u poredjenju sa pacijentima sa normalnom telesnom težinom, predgojazni i gojazni pacijenti imali su povecan nivo triglicerida a gojaznost je takodje bila znacajno povezana sa pojavom diabetes mellitusa tip 2, a naročito penzionera.

Dobijeni rezultati ukazuju na povezanost povecanog ITM sa ostalim kardiovaskularnim rizicima, a takodje sugerišu potrebu za zdravstvenim vaspitanjem i upoznavanjem pacijentata sa zdravim životnim navikama u cilju prevencije predgojaznosti i gojaznosti.

Ključne reči: stanje uhranjenosti, koronarna bolest, zdravstvene navike

\section{INTRODUCTION}

According to the World Health Organization (WHO), cardiovascular diseases are the major cause of death of 17.3 million people. Acute myocardial infarction is diagnosed in 6 million people, with more than $25 \%$ of cases leading to death (1). Cardiovascular diseases were responsible for $53.7 \%$ of all causes of death $(45.9 \%$ in men and $54.1 \%$ in women) in Serbia in 2013. In the total number of patients with heart disease, $55.7 \%$ of them had an ischemic heart disease $(2,3)$. It is believed that formation of atherosclerotic plaque, which is the basis of coronary heart disease starts 
with endothelial dysfunction (4) and that the main role is the retention of lipoprotein which increases the threshold for the development of endothelial stress (5).

Today it is also considered that the main developing factors of atherosclerosis are endothelial dysfunction, hemodynamic instability, inflammation and hypercholesterolemia. Chronic endothelial damage leads to endothelial dysfunction and increase of permeability, as well as the oxidation of LDL cholesterol and its accumulation in the intima (6). Risk factors of cardiovascular disease are divided into those that can be influenced, such as increased values of arterial blood pressure, elevated cholesterol levels, obesity, smoking, physical inactivity and diabetes mellitus as well as those on which we can't influence, such as gender, age, racial and ethnic affiliation and heredity (7).

\section{ObJeCtive}

The aim of this study was to assess the nutritional status in patients with coronary artery disease and to determine whether there is a link between nutritional status and some clinical manifestations of coronary artery disease (stable angina vs. acute coronary syndrome) as well as socio-demographic characteristics, health behaviors, and biochemical parameters.

\section{Methods}

The survey was conducted in a cross-sectional study in General Hospital in Pancevo for the period of 6 months (from December 2012 to May 2013). The study included 300 consecutive patients with diagnosed coronary heart disease. Clinical patients were divided into patients with stable angina pectoris and patients with acute coronary syndrome (patients with unstable angina pectoris and myocardial infarction). The diagnosis of stable angina pectoris was set up on the basis of history data on the existence of a typical angina pain at rest and/or electrocardiographic changes in terms of elevation/depression of ST segment $\geq 1 \mathrm{~mm}$ in at least two successive statements on the electrocardiogram and/or typical rise and fall of cardiac enzymes. The investigation did not include patients with malignant diseases. The examined patients were interviewed and the anthropometric measurements, laboratory analyses and clinical analyses were done.

Data on socioeconomic status and health habits (alcohol consumption, smoking, physical activity) were obtained using a specific questionnaire prepared for this study.

According to the degree of education, respondents were divided into three groups: less than 12 years of schooling; 12 years of education (secondary school), and over 12 years of school education.
As for smoking, patients were divided into three groups: smokers, former smokers and non-smokers. The current smoker is defined as a person who smokes at least one cigarette per day or who quit smoking within the previous year. Former smoker is a person who has not been smoking for more than a year and a non-smoker is a person who has never smoked.

Regarding alcohol consumption, patients were divided into three groups: those who consume alcohol now (people who drink $\geq 1$ alcoholic drink per month), those who consumed alcohol earlier (people who drank during the life of at least 12 alcoholic beverages but now they do not drink) and those who are non-drinkers (those who in the course of their lives have drunk fewer than 12 alcoholic beverages) (8).

Physical activity stands for every kind of unprofessional physical activity lasting $30 \mathrm{~min}$ per day during the previous month. Persons who exercised more than once a week were considered physically active and others were considered physically inactive.

Body weight (BW) and body height (TV) were measured by standard procedures. Body mass index (BMI) was calculated as the ratio of body weight $(\mathrm{kg})$ and height $\left(\mathrm{m}^{2}\right)$, and nutritional status was classified according to the World Health Organization (9).

Blood pressure was measured according to the recommendations by the Seventh Report of the Joint National Committee on Prevention, Detection, Evaluation and treatment of High Blood Pressure (10).

After twelve hours of fasting, blood samples were taken by cubital vein puncture to determine: glycemic and lipid status (triglycerides, total cholesterol, HDL and LDL cholesterol). Lipid and glycemic disorders were classified by the ATP classification (11).

\section{Statistical ANALYSIS}

Continuous variables were described as mean \pm standard deviation (SD), categorical variables as frequencies and percentages. In the analysis of data, $\chi^{2}$ test, and univariate and multivariate logistic regression methods were used. All variables which were according to univariate logistic regression analysis significantly associated with nutritional state at a level of $p \leq 0.10$ were included in the models of multivariate logistic regression analyses A two-tailed $p$ value of $<0.05$ was considered significant. All data were analyzed using version 20 of statistical package SPSS.

The study was approved by the Ethics Committee of the Medical Faculty in Belgrade. All patients gave written consent for participation in the study. 


\section{RESULTS}

The study group comprised 300 patients with coronary heart disease, 174 (56.8.00\%) men and $126(42.00 \%)$ women. Out of 300 patients with coronary heart disease, 68 (22.7\%) had normal weight, 133 (44.3\%) were overweight and 99 (33.0\%) were obese.

Since patients with stable angina pectoris (128 patients) and those with acute coronary syndrome (172 patients) did not significantly differ in their BMI (Table 1), further analyses were performed on all participants taken together.

Normal weight patients and overweight patients did not significantly differ in age, sex, marital status, education, occupation, smoking habit, alcohol consumption and physical activity (Table 2). In comparison with normal weight patients, obese patients were significantly younger $(p=0.032)$, more frequently women $(p=0.006)$, significantly more frequently blue collar workers $(\mathrm{p}=$ $0.002)$ and less frequently retired $(\mathrm{p}=0.001)$.

Out of clinical and biochemical characteristics presented in Table 3 , in overweight patients only increased triglycerides were significantly more frequent than in normal weight patients $(\mathrm{p}=0.005)$. In comparison with normal weight patients obese patients had significantly more frequently increased triglycerides $(\mathrm{p}=0.003)$, decreased level of HDL-cholesterol $(\mathrm{p}=0.022)$, and diabetes type 2 in personal history $(\mathrm{p}=0.011)$.

Table 1. Nutritional state according to body mass index in patients with various severity of coronary artery disease

\begin{tabular}{|c|c|c|c|c|}
\hline Variable & $\begin{array}{l}\text { Normal weight } \\
<25 \mathrm{~kg} / \mathrm{m} 2 \\
(\mathrm{n}=68)\end{array}$ & $\begin{array}{l}\text { Overweight } \\
25.0-29.9 \mathrm{~kg} / \mathrm{m}^{2} \\
(\mathrm{n}=133)\end{array}$ & $\begin{array}{l}\text { Obesity } \\
\geq 30 \mathrm{~kg} / \mathrm{m}^{2} \\
(\mathrm{n}=99)\end{array}$ & $\begin{array}{l}P \\
\text { value }^{*}\end{array}$ \\
\hline & $\mathrm{N}(\%)$ & N (\%) & $\mathrm{N}(\%)$ & \\
\hline Stable angina pectoris & $23(18.0)$ & $55(43.0)$ & $50(39,1)$ & \multirow[t]{2}{*}{0.093} \\
\hline Acute coronary syndrome & $45(26.2)$ & $78(45.3)$ & $49(28,5)$ & \\
\hline
\end{tabular}

* According to $\chi^{2}$ test.

Table 2. Demographic and some lifestyle characteristics of study participants by nutritional state according to body mass index

\begin{tabular}{|c|c|c|c|c|c|}
\hline \multicolumn{6}{|c|}{ Nutritional state (No. of participants (\%)/ mean \pm SD) } \\
\hline Characteristics & $\begin{array}{l}\text { Normal weight } \\
<25 \mathrm{~kg} / \mathrm{m}^{2} \\
\quad(\mathrm{n}=68)\end{array}$ & $\begin{array}{c}\text { Overweight } \\
25.0-29.9 \mathrm{~kg} / \mathrm{m}^{2} \\
(\mathrm{n}=133)\end{array}$ & $\begin{array}{c}\text { Obesity } \\
\geq 30 \mathrm{~kg} / \mathrm{m}^{2} \\
(\mathrm{n}=99)\end{array}$ & $\mathrm{p}^{\mathrm{a}}$ & $\mathrm{p}^{\mathrm{b}}$ \\
\hline Age $(\mathrm{X} \pm \mathrm{SD})$ & $67.7 \pm 10.8$ & $66.5 \pm 11.1$ & $64.2 \pm 9.7$ & 0.489 & 0.032 \\
\hline $\begin{array}{c}\text { Sex } \\
\text { Man } \\
\text { Woman }\end{array}$ & $\begin{array}{l}43(63.2) \\
25(36.8)\end{array}$ & $\begin{array}{l}90(67.7) \\
43(32.3)\end{array}$ & $\begin{array}{l}41(41.4) \\
58(58.6)\end{array}$ & 0.530 & 0.006 \\
\hline Marital status (married) & $47(69.1)$ & $90(68.2)$ & $67(69.1)$ & 0.893 & 0.995 \\
\hline $\begin{array}{c}\text { Occupation } \\
\text { Blue collar worker }\end{array}$ & $23(33.8)$ & $45(33.8)$ & $53(53.5)$ & $0.999^{c}$ & $0.013^{c}$ \\
\hline White collar worker & $8(11.8)$ & $23(17.3)$ & $17(17.2)$ & $0.307^{\mathrm{d}}$ & $0.339^{\mathrm{d}}$ \\
\hline Retired & $37(54.4)$ & $65(48.9)$ & $29(29.3)$ & $0.458^{\mathrm{e}}$ & $0.001^{\mathrm{e}}$ \\
\hline $\begin{array}{c}\text { Education } \\
\text { Elementary school } \\
\text { Secondary school } \\
\text { High school and faculty }\end{array}$ & $\begin{array}{c}33(48.5) \\
27(39.7) \\
8(11.8)\end{array}$ & $\begin{array}{c}67(50.4) \\
54(40.6) \\
12(9.0)\end{array}$ & $\begin{array}{l}60(60.6) \\
29(29.3) \\
10(10.1)\end{array}$ & 0.642 & 0.202 \\
\hline Ever-smokers & $47(69.1)$ & $82(61.7)$ & $59(59.6)$ & 0.297 & 0.210 \\
\hline $\begin{array}{l}\text { Alcohol consumption } \\
\text { (current and former) }\end{array}$ & $27(40.9)$ & $57(42.9)$ & $35(36.8)$ & 0.793 & 0.602 \\
\hline $\begin{array}{c}\text { Phisycal activity } \\
\text { (per one month): } \\
0-4 \\
5-8 \\
9-13 \\
\geq 14\end{array}$ & $\begin{array}{l}52(76.5) \\
5(7.4) \\
2(2.9) \\
9(13.2)\end{array}$ & $\begin{array}{c}89(67.9) \\
12(9.2) \\
4(3.1) \\
26(19.8)\end{array}$ & $\begin{aligned} 76 & (76.8) \\
6 & (6.1) \\
5 & (5.1) \\
12 & (12.1)\end{aligned}$ & 0.208 & 0.980 \\
\hline
\end{tabular}

${ }^{\text {a }} P$ value according to univariate logistic regression analysisfor comparison between overweight and normal weight group.

${ }^{\mathrm{b}} P$ value according to univariate logistic regression analysis for comparison between obese and normal weight group.

${ }^{c} P$ value according to univariate logistic regression analysis for comparison between blue collar worker/white collar worker and retired.

${ }^{\mathrm{d}} P$ value according to univariate logistic regression analysis for comparison between white collar worker/blue collar worker and retired.

${ }^{\mathrm{e}} P$ value according to univariate logistic regression analysis for comparison between retired/blue and white collar worker. 
Table 3. Some clinical and biochemical characteristics in study participants by nutritional state according to body mass index

\begin{tabular}{|c|c|c|c|c|c|}
\hline \multicolumn{6}{|c|}{ Nutritional state (No. of participants, \%) } \\
\hline Characteristics & $\begin{array}{l}\text { Normal weight } \\
<25 \mathrm{~kg} / \mathrm{m}^{2} \\
\quad(\mathrm{n}=68)\end{array}$ & $\begin{array}{c}\text { Overweight } \\
25.0-29.9 \mathrm{~kg} / \mathrm{m}^{2} \\
(\mathrm{n}=133)\end{array}$ & $\begin{array}{l}\text { Obesity } \\
\geq 30 \mathrm{~kg} / \mathrm{m}^{2} \\
(\mathrm{n}=99)\end{array}$ & $\mathrm{p}^{\mathrm{a}}$ & $\mathrm{p}^{\mathrm{b}}$ \\
\hline $\begin{array}{c}\text { Hypertension (blood pressure } \geq \\
130 / \geq 85 \mathrm{~mm} \mathrm{Hg} \text { ) }\end{array}$ & $57(83.8)$ & $118(88.7)$ & $93(93.9)$ & 0.591 & 0.115 \\
\hline $\begin{array}{c}\text { Increased triglycerides }(\geq 1.69 \\
\mathrm{mmol} / \mathrm{L})\end{array}$ & $39(57.4)$ & $101(76.7)$ & $78(78.8)$ & 0.005 & 0.003 \\
\hline $\begin{array}{c}\text { Low HDL - cholesterol }(<1.03 \mathrm{mmo}- \\
1 / \mathrm{L} \text { in men and }<1.29 \mathrm{mmol} / \mathrm{L} \text { in } \\
\text { women })\end{array}$ & $53(77.9)$ & $115(86.5)$ & $90(90.9)$ & 0.126 & 0.022 \\
\hline $\begin{array}{l}\text { Increased LDL - cholesterol }(\geq 3.40 \\
\mathrm{mmol} / \mathrm{L})\end{array}$ & $29(42.6)$ & $61(45.9)$ & 49 (49.5) & 0.664 & 0.384 \\
\hline Total cholesterol $\geq 5.2 \mathrm{mmol} / \mathrm{L}$ & $31(45.5)$ & $62(46.6)$ & $54(54.5)$ & 0.890 & 0.256 \\
\hline Diabetes Mellitus type 2 & $17(25.0)$ & $51(38.3)$ & $44(44.4)$ & 0.060 & 0.011 \\
\hline CVI/TIA & $11(16.2)$ & $11(8.3)$ & $9(9.1)$ & 0.095 & 0.171 \\
\hline Claudication & $13(19.1)$ & $42(31.6)$ & $27(27.3)$ & 0.063 & 0.227 \\
\hline Myocardial infraction & $33(48.5)$ & $54(40.6)$ & $46(46.9)$ & 0.284 & 0.840 \\
\hline
\end{tabular}

HDL - high density lipoprotein; LDL - low density lipoprotein; CVI/TIA - cerebrovascular insult/ transient ischaemic attack ${ }^{a} P$ value according to univariate logistic regression analysisfor comparison between overweight and normal weight group.

${ }^{\mathrm{b}} P$ value according to to univariate logistic regression analysis for comparison between obese and normal weight group

Table 4. Variables significantly related to nutritional state according to body mass index - multivariate logistic regression analysis

\begin{tabular}{lllll} 
& Overweigt vs normal weight & $\begin{array}{l}\text { Obesity vs } \\
\text { normal weight }\end{array}$ & & \\
Variable & OR $(95 \% \mathrm{CI})$ & $p^{\mathrm{a}}$ & OR (95\% CI) & $p^{\mathrm{b}}$ \\
\hline Increased & & & & \\
triglycerides $(\geq 1.69 \mathrm{mmol} / \mathrm{L})$ & $2.45(1.31-4.58)$ & 0.005 & $2.88(1.39-5.98)$ & 0.005 \\
\hline $\begin{array}{l}\text { Retired/blue and white collar worker } \\
\text { Diabetes mellitus type 2 }\end{array}$ & & & $0.30(0.15-0.59)$ & 0.001 \\
\hline
\end{tabular}

${ }^{a}$ In the model of multivariate logistic regression analysis were included: diabetes mellitus type 2, CVI/TIA, claudication and increased tryglicerides.

'In the model of multivariate logistic regression analysis were included: age, sex, blue worker/white worker and retired, retired/blue and white worker, diabetes mellitus type 2, low HDL level and increased tryglicerides

According to multivariate logistic regression analyses, in comparison with normal weight, overweight was significantly related to the increased level of triglycerides, and obesity was significantly related to diabetes mellitus type 2 and increased level of triglycerides and negatively with retirement.

\section{Discussion}

In this study, more than two-thirds of patients with CHD (77.3\%) had increased BMI, $44.3 \%$ were overweight, and $33.0 \%$ were obese. According to multivariate analysis, diabetes mellitus type 2 and elevated levels of triglycerides were statistically significant and independently associated with obesity. Among the obese there were significantly fewer people in retirement compared to the active population, especially blue collar workers. Being overweight was significantly associated only with high levels of triglycerides.
For a long time it was thought that CHD was more common among male population, but there are more and more studies that have proved that females are more often affected (12). Due to the increasing presence of obesity, diabetes and related comorbidities, cardiovascular disease showed an increasing trend among younger population, particularly among women, although in females the disease occurs 7-10 years later than in men (13). In our study $42 \%$ of patients were women.

Many factors, including sex hormones play an important role in the development of cardiovascular disease as well as differences in the epidemiological characteristics, treatment and prognosis of cardiovascular disease in men and women (12).

One study which included 70 patients with stable angina admitted to the Clinic of Cardiology, Military Medical Academy, Belgrade showed that there was a statistically significant positive correlation between the Finish Diabetes Risk Score (FINDRISC) which included age, BMI, waist circumference, physical (in) activity, diet, arterial 
hypertension, history of high glucose levels and diabetes mellitus in family history and the severity of CAD (14).

Hypertension, disorders of lipid status and diabetes are very important factors that explain this relationship (15).

In a prospective study of over 54000 persons, Jensen and colleagues proved that increasing of 1 unit of body mass index increases the risk of acute coronary syndrome in 5\%-7\% for both sexes (16). The incidence of obesity in patients with CHD in this study was similar to the prevalence in the study previously conducted on over 16.000 patients in 24 countries (17). Despite the fact that compared to the normal weight, obese patients are more likely to have not only CHD but also other atherosclerotic diseases, in the last decade there are more and more researchers who talk about obesity paradox which describes smaller incidence of mortality from CHD in obese patients. In a study that included more than 22000 patients, Uretski and associates (18) found that obese and overweight patients had a 30\% lower mortality compared to normal weight and underweight people.

The connection between elevated triglyceride levels and cardiovascular disease was also found in several studies, although the significance of hypertriglyceridemia as a risk factor for cardiovascular disease is still considered controversial (19). In a study that compared 3582 patients with CHD and 6175 control subjects (20), a significant relationship between triglyceride levels and cardiovascular risk was demonstrated. According to the results of a meta-analysis, which included over 56000 respondents, hypertriglyceridemia was an important risk factor for atherosclerotic disease (21). The same analysis showed that an increase of the levels of triglycerides for a $1 \mathrm{mmol} / \mathrm{L}$ increased the risk for cardiovascular disease by $32 \%$ in men and by $76 \%$ in women. In addition, more researches have shown that there is an inverse correlation between the levels of triglycerides and HDL (22). It is known that triglyceride levels that exceed the value of $1.69 \mathrm{mmol} / \mathrm{L}$ is a risk factor for CHD [11]. There is also an opinion that high triglyceride level is a stronger risk factor in association with other risk factors (23).

Hypertriglyceridemia in the obesity has been linked to insulin resistance and it is suggested that triglycerides in obese patients are increased as the result of dual metabolic defects, increased secretion and severely impaired clearance of triglyceride rich very-low-density lipoproteinparticles (24).

It is considered that there is the relationship of obesity and hypertriglyceridemia especially in insulin resistance and that the increased flux of fatty tissue, primarily free fatty acids, leads to an increase of triglyceride synthesis and secretion of VLDL particles (19).

The independent association between obesity and type 2 diabetes in this study is consistent with results of other studies that have shown that obesity, especially abdominal obesity, increases the risk of developing this type of diabetes even ten times, while the risk for hypertension and dyslipidemia is increased only twice (25). Vanamo and Saper (26) in their study pointed that the length of not only obesity but also of increased body weight, is an important factor in the development of diabetes type 2 . In patients who were overweight or obese five years or more, it was found that the risk of getting type 2 diabetes is four times higher than in patients who have had an increased body weight for a shorter period of time, and 8 times greater when it comes to obesity.

Recognizing the importance of diabetes in the development of cardiovascular disease, ATP III panel in 2001 accepted diabetes as equivalent to cardiovascular disease. Further on it contributed to further guidance in prevention measures (11). The mechanism of development of diseases such as CHD in people with type 2 diabetes is multifactorial, starting from the disruption of endothelial function, changes in the walls of arteries, oxidative stress, inflammation and many others (7).

Lower number of pensioners in the group of obese compared to active people, especially blue collar workers, in the present study, may be associated with worse social and economic conditions of pensioners. There is also a possibility that for blue collar workers who are physically active at work, which has a protective effect on CHD, obesity is a more important risk factor than for those who were physically inactive.

\section{LIMITATIONS OF STUDY}

This study had some limitations, first of all, the design of study was cross-sectional study. Although, the study was done at the General hospital in Pancevo, with a large number of patients, this data can not be considered representative for the territory of Vojvodina and Serbia.

\section{Conclusion}

The results obtained indicate the importance of obesity as a major risk factor for hypertension and coronary disease, and suggest the need to introduce patients to healthy lifestyle habits in order to prevent obesity and comoborbidity.

\section{FOUNDING SOURCES}

This work was supported by Ministry of Education, Science and Technological Development, Republic of Serbia, through contract no. III41002 (2011-2014). 


\section{References}

1. www.who.in

2. Health Statistical Yearbook of Republic Serbia. Institute of Public Health of Serbia. 2014

3. Incidence and mortality of acute coronary syndrome in Serbia. Register for acute coronary syndrome; 2011. (Serbian).

4. Cronenwett JL, Johnston KW, Liapis CD. Rutherford's vascular surgery (7th Edition): Role of risk factors. PA, USA: Elsevier Publishing. USA; 2010.8211p.

5. Williams KJ, Tabas I. The response-to-retention hypothesis of early atherogenesis. Arterioscler. Thromb. Vasc. Biol. 1995; 15: 551-61.

6. Marx N, Grant PJ. Endothelial dysfunction and cardiovascular disease--the lull before the storm. Diab Vasc Dis Res. 2007;4 (2):82-3.

7. http://www.world-heart-federation.org

8. Freiberg MS, Cabral HJ, Heeren TC, Vasan RS, Ellison RC. Alcohol Consumption and the Prevalence of the Metabolic Syndrome in the U.S.A cross-sectional analysis of data from the Third National Health and Nutrition Examination Survey. Diabetes Care. 2004; 27:2954-9.

9. World Health Organization. Obesity: Preventing and Managing the Global Epidemic: Report of a WHO Consultation on Obesity. Geneva: WHO;1998.

10. 1Seventh Report of the Joint National Committee on Prevention, Detection, Evaluation, and Treatment of High Blood Pressure. Hypertension 2003;42:1206-52.

11. Third report of the National Cholesterol Education Program (NECP) expert panel on detection, evaluation, and treatment of high blood cholesterol in adults (Adult Treatment panel III). Final report. Circulation. 2002; 106:3143-421

12. Ford ES, Capewell S. Coronary heart disease mortality among young adults in the US from 1980 through 2002: concealed leveling of mortality rates. J Am Coll Cardiol. 2007;50 (22):2128-32.

13. Maas AH, Appelman YE. Gender differences in coronary heart disease. Heart J. 2010; 18(12):598-603.

14. Djurić P, Mladenović Z, Grdinić A, Tavčiovski D, Spasić M, Davičević-Elez Z. Correlation between the Finnish Diabetes risk Score and the severity of coronary artery disease. Vojnosanit. Pregl. 2014; 71(5):474-80.

15. Poirier P, Giles TD, Bray GA, Hong Y, Stern JS, Pi-Sunyer FX, et al. Obesity and cardiovascular disease: pathophysiology, evaluation, and effect of weight loss: an update of the 1997 American Heart Association Scientific Statement on Obesity and Heart Disease from the Obesity Committee of the Council on Nutrition, Physical Activity, and Metabolism. Circulation. 2006; 113:898-918.
16. Jensen MK, Chiuve SE, Rimm EB, Dethlefsen C, Tjønneland A, Joensen AM et al. Obesity, behavioral lifestyle factors, and risk of acute coronary events. Circulation. 2008; 117:3063-9.

17. Kotseva K, Wood D, De Bacquer D, De Backer G, Rydén L, Jennings C, et al. on behalf of the EUROASPIRE Investigators. EUROASPIRE IV: A European Society of Cardiology survey on the lifestyle, risk factor and therapeutic management of coronary patients from 24 European countries. Eur J Prev Cardiol. 2015 (in press).

18. Uretsky S, Messerli FH, Bangalore S, Champion A, Cooper-Dehoff RM, Zhou Q, et al. Obesity paradox in patients with hypertension and coronary artery disease. Am J Med. 2007; 120(10):863-70.

19. Eckel RH. The complex metabolic mechanisms relating obesity to hypertiglyceridemia. Atheroscler Thromb Vasc Biol. 2011; 31(9):1946-8.

20. Sarwar N, Danesh J, Eiriksdottir G, Sigurdsson G, Wareham N, Bingham S, et al.Triglycerides and the risk of coronary heart disease: 10,158 incident cases among 262,525 participants in 29 Western prospective studies. Circulation. 2007;115(4):450-8

21. Hokanson JE, Austin MA. Plasma tryglyceride level is a risk factor for cardiovascular disease independent of high-density lipoprotein cholesterol level: a meta-analysis of population-based prospective studies. J Cardiovasc Risk. 1996: 3:213-9.

22. Di Angelantonio E, Sarwar N, Perry P, Kaptoge S, Ray KK, Thompson A, et al. Major lipids, apolipoproteins, and risk of vascular disease. JAMA 2009; 302:1993-2000.

23. Austin MA. Triglyceride, small, dense low-density lipoprotein, and the atherogenic lipoprotein phenotype. Curr Atheroscler Rep 2000; 2:200-7.

24. Taskinen MR, Adiels M, Westerbacka J, Söderlund S, Kahri J, Lundbom N, et al. Dual metabolic defects are required to produce hypertriglyceridemia in obese subjects. Arterioscler Thromb Vasc Bio 2011;31:2144-50.

25. Bonora E, Kiechl S, Willeit J, Oberhollenzer F, Egger G, Meigs JB, et al Population-based incidence rates and risc factor for tip 2 diabetes in white individulals: the Bruneck study. Diabetes. 2004;53:1782-9.

26. Wannamethee S, Shaper A. Weight change and duration of overweight and obesity in the incidence of Type 2 diabetes. Diabetes Care. 1999. 22(8):1266-72.

27. Yabin Wang, Qiujun Yu, Daiming Fan, and Feng Cao. Coronary heart disease in Type 2 diabetes: mechanisms and comprehensive prevention strategies. Expert Review of Cardiovascular Therapy. 2012 (10):1051-60. 